\title{
УКРАЇНСЬКІ РЕАЛІЇ ТА СВІТОВИЙ ДОСВІД ПРОТИДІЇ КОРУПЦІЇ У СФЕРІ ПУБЛІЧНИХ ЗАКУПІВЕЛЬ
}

Івашова Л.М., д-р наук з держ. упр., професор, Університет митної справи та фінансів, м. Дніпро, Україна

Івашов М.Ф., канд. екон., наук, с.н.с., професор, КЗВО «Дніпровська академія неперервної освіти», м. Дніпро, Україна

У статті проаналізовано сучасний стан та ефективність заходів з протидії корупиії в Україні, обтрунтовано актуальність дослідження досвіду протидї корупиії у світі та необхідність його імплементації до вітчизняної практики. Визначено основні механізми подолання корупиї у сфері публічних закупівель в Украӥні та першочергові заходи, щзо спрямовані на їх реалізачію.

Мета статті висвітлити реальний стан $і$ загрози від корупиії у сфері публічних закупівель для економічного розвитку Украӥни та на основі зарубіжного досвіду; визначити дієві механізми протидіі корупиії й напрями їх імплементації в Украӥні.

У ході дослідження використано та узагальнено офіиійно оприлюднені результати наукових досліджень вітчизняних $i$ зарубіжних авторів, статистичні дані, звіти державних контролюючих органів та міжнародних експертних організацій, творче осмислення яких на основі застосування системного підходу та методів статистичного та компаративного аналізу, контент-аналізу та синтезу отриманих результатів дозволило зробити обгрунтовані висновки.

У роботі обтрунтовано, щзо дієвими механізмами протидії корупиії $\epsilon$ подальший розвиток інституційного, інформаційнотехнологічного контрольного та моніторингового забезпечення механізму «електронних аукціонів», які за умови їх ефективного використання та активізацї громадянського суспільства здатні 
створити необхідне підгрунтя для зменшення обсягів та викорінення корупиії як у сфері публічних закупівель, так $і$ в інших сферах життедіяльності держави.

Визначено, щзо нині протидія зловживанням та боротьба з корупиією у сфері публічних закупівель в Україні, перебуває на досить низькому рівні. Тому подолання корупиї в системі розміщення державних замовлень є одним з найбільш важливих завдань державного управління у сфері публічних закупівель за бюджетні кошти. Позитивним у цъьому напрямі є те, щуо держава стала на шлях вироблення нових механізмів протидї корупиії-впровадження системи електронних закупівель ProZorro, запуск авторизованих електронних майданчиків та веб-порталу Уповноваженого органу з питань закупівель, проведення постійного контролю та моніторингу операцій з державних закупівель, розміщення результатів контролю на моніторинговому порталі DOZORRO тощя. Проте неефективне використання иих інструментів призводить до збереження високого рівня корупиії у сфері публічних закупівель.

Для підвищення ефективності протидії корупиії з урахуванням досвіду зарубіжних країн запропоновано: повністю відмовитися від розміщення замовлення у єдиного джерела без проведення торгів; удосконалити прочедуру оспорювання угод, укладених з порушенням вимог чинного законодавства. Це дозволить зменшити кількість зловживань та обмежить можливості застосування корупиійних схем у системі публічних закупівель за бюджетні кошти.

Загалом для успішного впровадження даних заходів передусім необхідно внести зміни до інституційного механізму державного управління системою публічних закупівель та посилити роль державного моніторингу та аудиту за обтрунтованим та иільовим використанням бюджетних коштів у системі публічних закупівель.

Ключові слова: публічні закупівлі, електронні аукціони, державний моніторинг і контроль у сфері закупівель, корупщія, протидія корупціiі.

Постановка проблеми у загальному вигляді. Наразі перед суспільством і владою в Україні гостро постала проблема протидії 
корупційним діянням у всіх сферах економічної діяльності, у тому числі й у сфері здійснення публічних закупівель, адже саме через цей інститут витрачається левова частка бюджетних коштів та здійснюється матеріально-технічне забезпечення усіх бюджетних організацій та установ. Зважаючи на те, що корупція це загально цивілізаційне лихо, й Україна не перша країна у світі, що стикається 3 iï масштабними проявами важливим є вивчення світового досвіду подолання цього явища та визначення основних умов його імплементації в Україні.

В Україні вже сформовано інституційні основи правової та організаційної протидії корупції. Однак незважаючи на зусилля держави, корупція, як неминучий наслідок з одного боку надмірного адміністрування, а з іншого відсутності ефективного контролю та відповідальності перед державою, як і раніше, перешкоджає проведенню соціальних перетворень і підвищенню ефективності національної економіки. I як справедливо зазначають науковці, це викликає в українському суспільстві тривогу й недовіру до державних інститутів, створює негативний імідж України на міжнародній арені й правомірно розглядається як одна із загроз економічній безпеці України [1, с. 3]. Тому дослідження проблем пов'язаних 3 корупцією й до цієї пори залишаються актуальними й вимагають наукового осмислення.

Аналіз останніх досліджень і публікацій. Актуальність зазначеної проблеми підтверджується значною кількістю зарубіжних та вітчизняних науковців, які займались розробкою проблем боротьби 3 корупцією в системі державних закупівель якій присвячена велика кількість наукових досліджень. Вагомий внесок у дослідження даної проблематики зробили С. Глодан, С. Дрьомов, Ю. Кальниш, Д. Клименко, Г. Усатий, Л. Усаченко, О. Критенко, Л.Пісьмаченко, К. Рудий, О. Тараненко, Н. Ткаченко, О. Шатковський, Г. Файвеш та багато інших учених. Вивчення зарубіжного досвіду публічних закупівель та протидії проявам корупційних діяльу цій сфері присвячено праці І. Бондара, О. Бучко, М. Бублія, Т. Кайдаш, О. Мiщенко, Р. Міщенко, С. Паппас, І. Сидоренко, Г. Харченко та інші. Проте в умовах трансформації політичної ситуації та становлення 
громадянського суспільства проблеми розробки сучасних заходів із запобігання корупції у сфері державних закупівель вимагають подальшого дослідження.

Формулювання цілей статті (постановка завдання). Мета статті висвітлити реальний стан і загрози від корупції у сфері публічних закупівель для економічного розвитку України та на основі зарубіжного досвіду визначити напрями протидії корупції й механізми їх імплементації в Україні.

Виклад основного матеріалу дослідження. Проблеми подолання корупції та іiї наслідків десятиліттями стоять перед українцями та Україною, але у тому, що корупція процвітає є також і вина усіх громадян. На жаль у суспільстві за роки незалежності нашої країни зміцнилися стереотипи толерантності до корупції та організованої злочинності, пов'язаної з нею. До того ж на думку окремих експертів, зокрема С. Глодана, в Україні тривалий час у масовій свідомості основних соціальних груп формувалася думка, що корупційні злочини не наносять шкоди суспільству, тому певні верстви населення обирали корупційні шляхи вирішення тих чи інших повсякденних проблем (чесний чиновник часто не влаштовує ні населення в цілому, ні підприємців, як його найбільш активну частину) [2]. Так, за даними соціологічного дослідження «СГ Рейтинг» в листопаді 2016 року від 20 до 40\% населення України було так чи інакше задіяне в корупційну діяльність в різних сегментах економічного, соціального або суспільного життя, що свідчить про толерантність майже половини населення України до корупції [18].

Результати Національного антикорупційного опитування, проведеного у липні-серпні 2018 року Програмою сприяння громадській активності «Долучайся!», що з 2007 року регулярно проводяться в Україні свідчать: абсолютна більшість громадян (понад 85 \%) вважають корупцію характерним для нашого суспільства явищем, майже дві третини (65,5%) вважають, що корупція дуже поширена, 21,2 \% - достатньо поширена. [19]. Проте наразі у суспільстві є розуміння тих загроз, які корупція несе для держави, адже за останніми даними соціалогічних досліджень корупція сприймається однією 3 трьох найбільших проблем в Україні, з переліку запропонованих до 
оцінювання респондентам (93,7\% громадян оцінили іiі як дуже або скоріше серйозну). Перше місце серед переліку проблем посідає висока вартість життя та низькі зарплати (95,8 \% опитаних назвали іiі дуже або скоріше серйозною), друге - військова операція на сході України $(93,9$ \%). При цьому обираючи між актуальністю різних типів корупції 92,5 \% опитаних назвали політичну корупцію на найвищому рівні дуже або скоріше серйозною проблемою. Повсякденну побутову корупцію, з якою можуть безпосередньо стикатися опитувані, вони вважають менш серйозною проблемою (81,6 \%). Корупцію у бізнесі вважають дуже та скоріше серйозною проблемою $72,4 \%$ опитаних [20].

Загалом населення України оцінює корупцію як зло, що руйнує державу, роз’ідає суспільну мораль, завдає шкоди всьому суспільству. Більшість населення України (56 \%) корупцію розуміють як хабарництво, продажність та підкуп посадових осіб, політичних діячів. Для інших корупція - це зловживання владою, перевищення посадових повноважень для власного збагачення. Проте якщо у 2006 році, згідно з даними Агентства Сполучених Штатів з міжнародного розвитку (USAID), основними причинами корупції в Україні були слабка система правосуддя, засилля контролюючих органів, непрозорий уряд, що пов'язаний з бізнесом політичними зв'язками, а також слабке громадянське суспільство [21], то у 2018 цей перелік значно розширився й до нього ввійшли, також, такі пункти як: відсутність адекватного покарання за корупцію; нечесність політиків та державних службовців; звичка населення вирішувати все за допомогою в т.ч. корупції; відсутність чітких процедур і правил в діяльності державних органів, а також низький рівень поінформованості населення про існуючі процедури та правила роботи державних інституцій [20]

Щодо негативного впливу корупцію на розвиток сфери публічних закупівель, то ще у 2011 році було визнано, що корупція позбавляє державний бюджет 2,5 млрд дол. доходів на рік, і через корупційні оборудки в галузі державних закупівель у кишенях чиновників осідають від 10-15 \% (7,4 млрд дол.) бюджетних коштів [22].

Трансформація української політичної системи, яка розпочалася під тиском громадськості після «революції гідності» характе- 
ризується зростанням ролі громадянського суспільства та початком формування нової якості стосунків у трикутнику «громадянин громадянське суспільство - держава». Оскільки сьогодні корупція $\epsilon$ «соціальною хворобою» українського суспільства [5], то її подолання у значній мірі залежить від оздоровлення суспільства й активності його громадян.

Одним із головних показників зміцнення громадянського суспільства $є$ розуміння громадянами особистої відповідальності за стан суспільного життя: в економічній, політичній, соціальній та інших сферах. Сьогодні більшість населення України усвідомлює, що саме їм, громадянам, належить вирішальна роль у виконанні законів, що прагнення змінити державу не можна покладати лише на політиків. Так, за даними соціологічного дослідження «Стан корупції в Україні», проведеного Київським міжнародним інститутом соціології у липні-жовтні 2015 р., частка населення, яка покладає основну відповідальність за подолання корупції на простих громадян зросла з 15,7 \% у 2007 р. до 24 \% у 2015 р. [23] та впала до 10,8 \% у 2018 р. [20], що свідчить про зневіру громадян у дієвість впливу громадянського суспільства на корупційні оборудки влади. Із запуском системи електронних державних закупівель ProZorro особливо мінімізовано було вплив громадскості на систему державних закупівель, шо чиновники намагалися пояснити досконалістю системи, яка суттєво зменшує корупційні ризики.

За даними загальнонаціонального опитування громадської думки, проведеного Фондом «Демократичні ініціативи» імені Ілька Кучеріва та Київським міжнародним інститутом соціології з 8 по 20 жовтня 2015 р., половина респондентів вважало, що за останні два роки зросла готовність громадян до захисту своїх прав, свобод та гідності, а також їх прагнення до об'єднання через створення громадських організацій та рухів. При цьому $57 \%$ опитаних громадян проявляють дедалі більшу готовність безоплатно приділяти свій час суспільно корисним справам; 60 \% відзначають зростання готовності громадян України до пожертвування особистих коштів на корисні справи; $41 \%$ - їх всезростаючу зосередженість на громадській діяльності; 43\% впевнені у тому, що зросла готовність громадян до 
активної участі в політиці; 44 \% побачили посилення інтересу громадян до участі у контролі за діяльністю влади; 39 \% вважають, що за два останніх роки громадяни беруть більшу участь у місцевих справах місцевої громади; 56 \% - що за останні два роки зросла готовність громадян до участі у масових акціях протесту чи підтримки [24].

Наразі не зважаючи на певні кроки владних інституцій на подолання корупції, що, на жаль, виявилися малоефективними, боротьба 3 корупцією залишається пріоритетом для українського суспільства. Одним із головних напрямів громадської активності в нинішніх умовах $є$ реагування на внутрішні загрози національній безпеці України, зокрема, на зволікання із проведенням реформ та тотальне ураження корупцією органів державної влади. Слід зазначити, що громадський сектор активно включився у вирішення цих проблем та досяг певних позитивних результатів [25].

Безперечно, що успіх процесу реформування напряму залежить від зменшення рівня корумпованості органів державної влади. Усвідомлення цього зв'язку громадськістю в нових суспільно-політичних умовах, що склалися після подій 2014 року, сприяло появі нових антикорупційних громадських об'єднань та громадських ініціатив.

В Україні найбільш успішними антикорупційними громадськими проектами за останні роки є:

- проект «УКР.АВ», розпочатий у 2014 р. громадською організацією «Центр протидії корупції», який фіксує на власному електронному ресурсі докази проти конкретних чиновників корупціонерів та відображає протікання процесу притягнення їх до відповідальності з розкриттям інформації про всі спроби контролюючих чи правоохоронних органів покриття корупціонерів;

- проект «Наші гроші», який представлено на окремому сайті, що займається моніторингом і аналізом інформації опублікованої у «Віснику державних закупівель» на предмет виявлення можливих корупційних ризиків;

- система електронних державних закупівель ProZorro, введена в експлуатацію у лютому 2015 р. при фінансовій підтримці громадської організації «Transparency International Ukraine», що спря- 
мована на забезпечення прозорості та ефективності використання бюджетних коштів, запобігання корупції завдяки громадському контролю та розширенню кола постачальників.

Значна частина громадян України переконана, що має брати участь у діяльності громадських об'єднань, зокрема у здійсненні ними контролю за державними органами. Необхідно зазначити, що 3 початком кризи довіра до громадських організацій знизилася порівняно менше, ніж довіра до інших соціальних інститутів. Можна стверджувати, що суспільство покладає надії на те, що розширення діяльності громадських організацій, інших структур громадянського суспільства може посприяти реформуванню держави та суспільства. Повернути довіру громадян може широке залучення структур громадянського суспільства на національному та на місцевому рівнях до розробки та прийняття заходів антикризової політики у політичній та соціально-економічний сферах. На місцевому рівні громадським об' єднанням треба надати не лише контролюючі функції, зокрема у сфері боротьби з корупцією, розподілу соціальної допомоги, але право брати безпосередню участь у вирішенні конкретних завдань у цій сфері, у залучені громадян до волонтерської роботи.

Розповсюдженість корупційної поведінки, перетворення іiі для значної маси населення на норму зовсім не означає, що в суспільстві не залишається людей, які не сприймають корупцію, хабарництво у будь-якому вигляді. Наразі $є$ певні соціальні групи зацікавлені в існуванні корупції, проте більшість населення України хоче жити в правовому, соціально здоровому суспільстві.

Державні й приватні втрати від закупівель за завищеними цінами досягли в нашій країні вражаючих розмірів. Через корупційні оборудки у сфері державних закупівель збитки становлять 10-15 \% (35-52,5 млрд грн.) видаткової частини держбюджету щорічно [3, 26], що наразі становить певну загрозу не лише для України, але й для світової фінансової системи [5].

Так, за даними Держаудитслужби України станом на 27 червня 2019 року, тобто за останні пів року під моніторинг закупівель потрапили майже 4,3 тис. закупівель. Як наслідок, за висновками аудиторів замовники відмінили процедур закупівель загальною очі- 
куваною вартістю майже 5,4 млрд грн. та розірвали договорів більш ніж на 660 млн грн. [27].

Зауважимо, що аудитори визнають, що моніторинг дійсно ефективний механізм у запобіганні порушенням. Водночас фахівці визнають, що за окремими параметрами він вимагає вдосконалення, а саме необхідно: розширити функціональні можливості електронного кабінету, особливо чимало проблем та недоліків, які потребують технічного розв'язання; поліпшити ризикорієнтовану систему відбору процедур, адже технічні можливості електронної системи закупівель не дають змоги впровадити автоматичні індикатори ризиків, які свідчили б про наявність ознак порушень під час кваліфікації учасників та подальшого вибору переможця [27]. Тому наразі необхідно вдосконалити проведення та реалізацію моніторингу закупівель і механізм попередження порушень, а також посилити відповідальність замовників за невиконання ними вимог законодавства.

Також фахівцями зазначається, що у разі таких порушень, як закупівля товарів, робіт і послуг без застосування визначених законодавством процедур та неоприлюднення, порушення порядку оприлюднення інформації про закупівлі відповідно до вимог законодавства, органи держфінконтролю можуть складати протокол про адміністративне правопорушення за статтею 164-14 Кодексу України про адміністративні правопорушення. Однак доволі часто зробити це їм не вдається через брак доступу до необхідних персональних даних порушників [28]

У більшості країн держава є найбільшим споживачем на ринку, частка державних закупівель становить 10-20 \% ВВП [11]. За XX століття частка державних витрат у ВВП збільшилася практично у всіх країнах, причому відзначено збільшення, як обсягу, так і вартості державних закупівель. Це зростання супроводжувалося розвитком законодавства у сфері закупівель для державних потреб. У США, наприклад, частка державних закупівель дорівнює приблизно 15 \% видаткової частини національного бюджету [12]. Ще вище частка державних закупівель в країнах, де державне управління істотно впливає на економіку (Німеччина, Франція та ін.). У державах 3 перехідною економікою частка державних закупівель у видатковій 
частині національного бюджету досягає 50 \% [17]. Настільки значні обсяги державних закупівель роблять завдання забезпечення їх ефективності першорядною.

Досвід зарубіжних країн показує, що найбільш ефективним і дієвим механізмом закупівель за державні кошти є проведення публічних конкурсів. Публічність процесу розміщення державних замовлень немає альтернативи, оскільки закритість процедури публічних закупівель породжує корупцію і нецільве та неефективне витрачання бюджетних коштів.

У більшості країн (США, Японії, Німеччина, Франції, Італії. Нідерландах, Іспанії та ін.) державні закупівлі регулюються спеціальним законодавством, в інших - відомчими інструкціями [29]. В ЄС розроблено та введено в дію шість основних директив, які врегульовують процедури закупівель товарів, робіт та послуг за державні кошти:

- Директива Ради 93/36/СЕС (про державну закупівлю товарів);

- Директива Ради 93/37/СЕС (про державну закупівлю робіт);

- Директива Ради 92/50/СЕС (про державну закупівлю послуг);

- Директива Ради 89/665/СЕС (про засоби суспільно-правового захисту);

- Директива Ради 93/38/СЕС (щодо підприємств 3 надання комунальних послуг);

- Директива Ради 92/13/СЕС (про засоби судового захисту підприємств з надання комунальних послуг) [7].

Основна ціль європейських директив - уніфікація процедур державних закупівель, вартість яких перевищує порогові значення. Ці директиви є обов’ язковими для всіх країн членів СС. До того ж, у законодавстві СС визначено, що всі державні підприємства, організації та установи, у тому числі й ті, що надають послуги у сферах транспорту, телезв'язку, водопостачання та енергопостачання, повинні керуватися такими принципами як відсутність дискримінації та прозорість процедур здійснення закупівель.

Для аналізу процедур у сфері публічних закупівель та механізмів протидії корупції у цій сфері розглянемо досвід Сполучених Штатів Америки (далі - США), Великобританії, Канади, Швейца- 
piï, Японії, країн - членів СС, тобто країни з високорозвиненим i відкритим ринком, що мають багатий, накопичений роками досвід, а також таких близьких до України в інституціональному та економічному середовищі країн, як Молдова, Польща, Угорщина, Чехія і Словаччина.

При дослідженні міжнародної практики державних закупівель ми дійшли висновку про те, що процеси глобалізації та стирання кордонів зумовили перехід багатьох держав на широке використання інструментів «нової економіки» для підвищення ефективності процедур державних закупівель та залучення до участі в торгах більшої кількості постачальників (в тому числі і іноземних) [14, 30]. Застосування інформаційних технологій стало визначальним фактором розвитку системи розміщення замовлень у багатьох державах.

Наразі в Україні етап становлення системи електронних торгів знаходиться в стадії активного впровадження. Багато провідних держав світу вже сформували у своїх законодавствах правові основи для застосування електронних способів закупівель. Такі держави, як Австрія, Канада, США вже сформували умови для застосування електронних способів закупівель завдяки впровадженню механізмів електронного цифрового підпису, що є невід'ємною умовою проведення зазначених закупівель $[6 ; 8 ; 11 ; 14]$.

Ознакою розвиненої системи розміщення замовлення є наявність можливості оскарження не правочинних дій державного замовника. Українська практика оскарження рішень державних замовників, або порушення процедур розміщення замовлення має на увазі як судовий порядок, так і адміністративний. Відповідно до останнього Закону України «Про публічні закупівлі» [31], постачальнику надається можливість направити скаргу до органу оскарження на дії державного замовника протягом 14 днів з отримання суб' єктом оскарження повідомлення про відповідне рішення чи дію замовника, що порушує права чи законні інтереси суб'єкта скарження, або з дня, коли суб'єкту оскарження стало відомо про порушення його прав чи законних інтересів прийнятим рішенням, дією чи бездіяльністю замовника, але до моменту укладення договору про закупівлю [31]. Якщо постачальник не встиг звернутися в контроль- 
ний орган протягом встановленого терміну йому надана можливість оскаржити дії державного замовника в судовому порядку.

Досвід зарубіжних країн, особливо з розвиненою ринковою інфраструктурою, показує, що система державних закупівель стала складовою частиною сфери внутрішнього товарообміну певними видами продукції і послуг і одним із механізмів підтримки конкуренції та ліберального способу господарювання [9].

Основою існування і розвитку системи державних закупівель в національній економіці багатьох країн $є$ той факт, що в процесі виконання своїх функцій державні відомства стикаються з проблемою матеріально-технічного забезпечення як для реалізації державних програм, так і для власної діяльності. Як правило, вона розв'язується шляхом придбання необхідних товарів, робіт і послуг через державні закупівлі на основі проведення електронних конкурсних торгів [8]. Застосування конкурсного механізму дозволяє: зменшити вартість, забезпечити прозорість процесу, протидіяти корупції.

На стрімкий розвиток системи державних закупівель вплинув $\mathrm{i}$ той факт, що держава тепер виступає активним суб'єктом ринкових відносин і бере безпосередню участь у виробничих, торговельних, інноваційних, інвестиційних та соціально-економічних процесах. До того ж саме державні закупівлі в зарубіжних країнах стали одним з основних інструментів державного регулювання та контролю при виконанні програм у сфері будівництва великих промислових об'єктів, транспортних сполучень, нафто- і газопроводів, а також під час реалізації освітніх і соціальних проектів.

Аналізуючи досвід різних країн у сфері державних закупівель, ми виявили як багато спільних рис, так і певні відмінності, що пов'язані, насамперед, 3 різним розумінням самого поняття «державні закупівлі». У країнах СС вони пов'язані з придбанням продукції та послуг для суспільних цілей (public procurement), а в інших країнах до цього поняття зараховують закупівлі для державних потреб (government procurement) [17]. На нашу думку, перше поняття $є$ ширшим, тому що охоплює забезпечення потреб не тільки державних установ і підприємств, а й комунальних служб і більш детально відображає фінансові витрати держави на такі цілі. 
Світова практика доводить також, що форма державного устрою безпосередньо впливає на ступінь централізації системи державних закупівель та рівень іiі законності. Наприклад, у Польщі, Угорщині, Словаччині, Чехії, Молдові і Латвії всі закупівлі для державних потреб регулюються однаково для всіх рівнів влади за одним законом, який базується на типовому законі UNCITRAL [16; 17]. Однак варто зазначити, що серед законодавчих актів перелічених країн найскладніший угорський, бо там, крім Закону про державні замовлення, існує низка інших нормативних документів, які містять особливі правила, що використовуються для певних видів процедур (поставки для військових або поліцейських цілей, парфумерної та електронної продукції, а також для процедур, що стосуються державних таємниць). Схожі законодавчі норми для різних секторів економіки $\epsilon$ і в законодавстві Словаччини.

У Швейцарії державні закупівлі регулюються відповідно до конституційного розподілу повноважень: ті, що належать до компетенції федеральної влади, регламентує федеральне законодавство, а кантональні, міжкантональні та місцеві - законодавство на рівні кантонів і місцевих органів влади [9, с. 42].

Канада хоч і має федеральний державний устрій, проте державні закупівлі країни не регулюються єдиним нормативно-правовим актом. Кожна провінція тут має право самостійно визначати політику у сфері держзакупівель за умови, що вона не буде суперечити міжнародним угодам і угодам між провінціями та урядом $[10$, c. 43$]$.

Законодавчу основу системи державних закупівель у США становлять Правила закупівлі для федеральних потреб і Правила для потреб державної оборони. Ці два нормативно-правові документи регламентують усю систему федеральних закупівель і відомі досить детальною розробкою принципів і процедур. Усі закони, що регулюють державні закупівлі в цій країні, можна поділити на дві категорії. Федеральне законодавство регламентує здійснення конкретних видів закупівель, які належать до компетенції органів виконавчої влади на федеральному рівні. Спеціальне законодавство регламентує здійснення процедур за контрактами, форми контрактів, визначає 
порядок формування й використання інформаційного забезпечення процесів держзакупівель та аналіз їх результатів [12].

Майже у всіх країнах декларується, що система державних закупівель має грунтуватися на принципах економії, ефективності, справедливості, боротьби з корупцією та мінімізації витрат на проведення державних закупівель, існує також система контролю за дотриманням цих принципів, що й робить більш ефективним цей механізм.

Слід зазначити, що основні вимоги міжнародних угод про закупівлі імплементовані в національне законодавство багатьох країн. I якщо Угорщині, Польщі, Латвії та іншим країнам колишнього соціалістичного блоку довелося вносити суттєві зміни до свого законодавства, то в Японії, де закон про держбюджет, окрім іншого, описує загальні процедури прок'юременту, підлягали змінам тільки нормативні положення цього Закону [11].

Не дивлячись на те, що країни Центральної та Східної Європи уніфікували законодавство згідно з вимогами СС, все одно до подолання надмірної бюрократизації у сфері держзакупівель ще далеко. Наприклад, у Словаччині закон про державні замовлення вимагає наявності документації, одержати яку на практиці дуже важко. Також формальні вимоги стосовно подання заявки на участь у тендері надміру деталізовані.

Більшість досліджених країн блокує доступ іноземних учасників, тим самим підтримуючи національних виробників шляхом надання їм преференцій у сфері державних закупівель. Наприклад, в Японії контракти на державні замовлення вкрай рідко укладаються 3 іноземними кампаніями, тут оцінюється ділова репутація і ментальна близькість національних партнерів. У Канаді такий самий стан справ пов'язаний з патріотичними мотивами та прагненням уряду продемонструвати бережливе ставлення до грошей платників податків [10, с. 44]. У Польщі також замовники і суди не схильні визнавати учасників, які зареєстровані за межами країни, i, як правило, приймають рішення про їх дискваліфікацію. Чехія, навпаки, максимально сприяє участі в конкурсі учасників з інших країн; наприклад, можна подавати документи відповідно до чеського законодавства, але оформлені за законами своєї країни [32]. 
Що стосується інформаційного забезпечення, то канадський досвід інформування громадськості про державні закупівлі за допомогою мережі Інтернет нараховує близько десяти років, тоді як в Україні впровадження електронних інформаційних технологій тільки розпочинається. У Канаді інформація про федеральні закупівлі й закупівлі провінцій публікується за допомогою системи MERX, яка не $є$ державною власністю, на відміну від українського офіційного сайту, котрий належить Міністерству економіки. Відмінність і в тому, що державні замовники в Канаді оплачують розміщення відомостей у системі MERX, а за розміщення даних на офіційному сайті України плата не стягується [10]. Проте можна виділити й спільні риси: безкоштовне надання інформації та фінансування з державного бюджету.

На окрему увагу заслуговує досвід застосування інформаційної електронної мережі США. Нині кожне федеральне відомство Америки зобов'язане формувати й підтримувати ведення комп'ютерної бази даних, що містить несекретні відомості, за всіма контрактами. Усі відомства повинні спрямовувати таку інформацію до Центральної інформаційної системи федеральних закупівель, яка є джерелом консолідованої інформації про державні закупівлі та містить дані з 1979 р. Ці відомості використовуються як основа для формування періодичних та спеціальних звітів президентові, Конгресові, Бюджетному управлінню США, а також надаються федеральним відомствам, діловим групам і громадськості. На платній основі надаються звіти, що складаються за індивідуальними запитами споживачів. У той же час треба наголосити й на деяких недоліках системи: неповне надання даних окремими федеральними відомствами та невелика активність використання інформаційних ресурсів як 3 боку урядових відомств, так і з боку громадськості [12].

Інформаційні ресурси забезпечують реалізацію зазначених вище принципів: публічності процесу закупівель продукції для державних потреб, рівноправності у процесі закупівель і відкритого доступу до інформації про укладені контракти. Отже, використання інформаційних електронних мереж дозволяє підвищити ефективність державних закупівель і покращує зв'язок між учасниками тендеру і його організаторами. 
Закупівлі на конкурсній основі є основним механізмом закупівель товарів, робіт і послуг для державних потреб у більшості країн світу. Процедури проведення конкурсів регламентуються як законодавством, так і різного роду рекомендаціями різних органів або громадських організацій.

Стосовно організації конкурсних торгів вважаємо за необхідне зазначити таке. У світовій практиці використовуються певні механізми організації закупівель за бюджетні кошти для державних потреб. Найбільш розвинений і найчастіше використовується метод закупівель, що передбачає участь усіх зацікавлених постачальників і підрядників, які відповідають кваліфікаційним вимогам, що опубліковуються в оголошенні про проведення закупівлі, i, як правило, контракт присуджується пропозиції з найменшою ціною. Майже в усіх досліджених країнах він має назву відкритих або публічних закупівель (торгів), окрім Канади, де організація торгів у такий спосіб називається запрошенням до участі.

Також серед конкурсних закупівель виділяють закриті торги, торги, на яких відбувається продаж-купівля товару на конкурсних засадах, для вузького (заздалегідь визначеного) кола покупців або без участі покупців. Закриті торги плануються і здійснюються спеціальним комітетом на підставі попередніх письмових замовлень покупців.

Крім відкритого й закритого конкурсів, застосовуються такі спрощені способи закупівлі зі збереженням елементів конкуренції, як запит котирувань (запит цін, цінових оферт), що використовується при закупівлях стандартних товарів, робіт і послуг, як правило, на невелику суму.

За загальним правилом заборонено проведення переговорів 3 постачальником. Наприклад, у Латвії переговори виділені в окремий метод проведення закупівель, але до нього звертаються лише тоді, коли пропозиції відкритого або закритого конкурсу не відповідають кваліфікаційним умовам або коли бракує часу для їх проведення [16, с. 38].

Існують випадки, коли без переговорів неможливо сформулювати вимоги до предмета закупівлі, наприклад у разі проектних робіт 
або дизайну в будівництві. Тоді практикою багатьох країн (Україна, Молдова, країни СС, США, Канада) передбачено проведення процедури двоступеневих торгів. У США він має назву конкурсу з подачею пропозиції, в Канаді - запиту пропозиції. У цьому випадку на першому етапі збираються пропозиції без зазначення їхньої вартості, далі організатор конкурсу за результатами переговорів уточнює вимоги до поставки. На другому етапі подаються остаточні заявки із цінами й відбувається вибір переможця.

Інші країни при обмеженому колі постачальників застосовують селективні процедури (Швейцарія, Японія).

Застосування такої процедури, як електронні торги для здійснення державних закупівель наразі почали активно використовувати у США. Метою впровадження електронних торгів для федеральних закупівель $є$ не лише автоматизація взаємодії закупівельних органів з потенційними підрядниками, як того вимагає Закон про вдосконалення федеральних закупівель від 1994 р., а й зниження витрат на виконання закупівельних процедур і скорочення термінів проведення цих операцій [12, с. 40].

Важливою умовою застосування електронних торгів $\epsilon$ ефективне та розвинене законодавство у сфері регулювання використання інтернет-технологій, засобів зв'язку і захисту інформації, а також наявність базових стандартів безпеки для комп'ютерних мереж.

Окрім конкурсних, у багатьох країнах широко використовується позаконкурсна процедура - закупівлі в одного учасника (Швейцарія, Японія, Польща, Молдова, Україна). Зазвичай ця процедура застосовується в таких випадках: екстремальна ситуація, наявність тільки одного учасника, закупівлі предметів, які захищено особливими правами або патентом, закупівлі для досліджень чи розробок або якщо необхідно провести додаткові закупівлі у постачальника, 3 яким раніше вже було укладено контракт.

Як показує практика багатьох країн у сфері державних закупівель, контракт присуджується за найменшою ціною за умови, що ціна не перевищує максимально допущену ціну або попередню оцінну вартість контракту. Якщо всі пропозиції перевищують бюджет закупівлі, то тендер проводиться повторно. В Японії для того, 
щоб запобігти негативному ефекту «нижча ціна - нижча якість», використовували метод «мінімально допущена ціна». Проте Кабінет міністрів України заборонив його використання, а натомість запропонував «систему дослідження низької ціни», яка полягає в аналізі пропозицій із занадто мінімальною ціною та їх відхилення за необхідності [14]. Але зауважимо, в таких секторах, як космічні та військові технології, медичне обладнання, телекомунікації, не тільки ціна є визначальною.

Наприклад, канадські федеральні закупівельні агентства протягом багатьох років включали в свої контракти положення, яке вимагає від постачальника дотримання недискримінаційних процедур при найманні через «расове, національне походження, релігію, вік, стать або сімейний стан». Також державні замовники зобов'язані вживати заходи для виявлення та усунення всіх «штучних бар'єрів при відборі, наймі, кар'єрному просуванні і підвищенні кваліфікації жінок, корінного населення, інвалідів» і покращувати ситуацію з зайнятістю [10]. Це стосується всієї сфери діяльності постачальника, а не тільки замовлень, які виконуються за державними контрактами. Якщо ж в іншій діяльності постачальника будуть виявлені відхилення від цього принципу недискримінації кадрів, то його можуть відсторонити від усіх федеральних державних контрактів. Аналогічні вимоги можна знайти і у федеральній політиці по закупкам США, зокрема, щодо охорони навколишнього середовища, що застосовуються до постачальників [12, с. 42].

Позитивний і вартий уваги досвід Великобританії. Спеціально уповноважений орган з координації та контролю за державними закупівлями країни безкоштовно розповсюджує інформаційний каталог (у паперовому й електронному вигляді) з різними пропозиціями товарів і послуг. Використовуючи його, розпорядники державних коштів мають змогу замовити певний товар або послугу, не проводячи формально процедуру закупівлі, оскільки вона вже була проведена за запропонованими групами товарів цим уповноваженим органом [32, с. 34].

Для проведення закупівель практикується пред’явлення попередніх кваліфікаційних вимог. Це можуть бути вимоги щодо подання 
інформації про чисельність працівників, їх кваліфікацію, дані про виробництво, річний баланс, фінансові звіти, підтвердження про сплату податків, аудиторський звіт, якість виконання попередніх контрактів [4]. На основі таких даних у деяких країнах світу складаються списки потенційних постачальників. Проте включення до такого списку ніяк не гарантує право бути запрошеним до подання пропозицій конкурсних торгів у випадку селективного тендеру. А виключення з нього можливе не тільки при втраті відповідності вимогам, коли, наприклад, у Швейцарії буде встановлено факт дискримінації праці жінок або порушення стандартів безпеки і умов праці. В Японії постачальник може бути дискваліфікований, якщо був доведений факт корупції при проведенні тендеру. Ці правила не тільки прописані в законах, а й широко застосовуються на практиці [17].

Тобто відповідність постачальників і підрядників критеріям кваліфікаційної оцінки автоматично дає відповідь на запитання: чи може зазначена компанія якісно виконати контракт за визначеним обсягом і у встановлений термін, чи достатньо для цього її фінансових ресурсів, потужностей та кваліфікованого персоналу.

У деяких країнах світу, наприклад у Польщі, для того щоб уникнути подачі нереальних пропозицій, при проведенні конкурсу практикується вимога внесення застави. В Японії такий захід має назву банківська гарантія, як правило, розміром не більше $5 \%$ від суми контракту. При високій вартості контракту практикується забезпечення пропозицій від учасників конкурсу у розмірі від 0,5 до $3 \%$ вартості контракту [15, с. 56].

Учасники конкурсу повинні бути сповіщені про його результати і мають право їх заперечувати у випадку, якщо переможця обрано 3 порушенням правил. При істотних порушеннях конкурсних процедур результати можуть бути визнані недійсними, що тягне за собою розірвання контракту. Проте у Швейцарії навпаки, якщо контракт вже був укладений, то рішення не може бути анульовано, і Федеральна апеляційна комісія може тільки констатувати, що федеральний закон порушено без будь-яких санкцій до порушників [9].

Оскарження дій державного замовника може проводитись у досудовому і в судовому порядку. До суду справа доводиться рідко, 
тому що майже у всіх країнах існує спеціальний орган влади, до функцій якого належить розв'язання суперечок між державними замовниками й постачальниками. У Канаді функції з контролю за дотриманням законодавства й вирішення спірних питань виконує Канадський міжнародний торговельний трибунал (CITT). Рішення CITT мають юридичну силу і обов'язкові для всіх державних замовників [10, с. 42].

У США після розгляду скарги на дії замовника можуть бути прийняті такі рішення:

1) продовжити закупівлі, якщо порушення не вплинули на процес закупівлі;

2) почати розслідування;

3) передати інформацію слідчим органам.

Законодавством США (Закон Шермана) передбачаються штрафні санкції й карне переслідування [12].

У країнах ЄС і Японії основними механізмами санкцій є розірвання контракту і оскарження дій замовника в судовому порядку [17].

За умови доведення факту порушення постачальникові, права якого були порушені, компенсуються тільки витрати, пов'язані 3 участю в тендері. Втрачені майбутні прибутки або вигоди не компенсуються.

Підсумовуючи вищесказане, узагальнимо:

- в законодавстві багатьох країн широко поширені преференції та інші заходи з підтримки вітчизняних постачальників, задекларована рівність вітчизняних та іноземних постачальників при розміщення державного замовлення ускладнюється обмеженнями, технічними стандартами та іншими бар'єрами;

- важливу роль у підвищенні ефективності розміщення замовлень відіграє інформаційна складова державних закупівель. Процес глобалізації викликав численні тенденції до застосування світовим співтовариством передових інструментів «нової економіки», зокрема широке поширення серед багатьох країн набуло застосування електронних засобів розміщення замовлення. Широке застосування ресурсів мережі Інтернет зумовило напрям вдосконалення сис- 
теми державних закупівель в усьому світі, а саме - застосування електронного інструментарію та мережі Інтернет для розміщення замовлень в режимі online. Очевидні тенденції заміщення звичайних процедур розміщення замовлення їх електронними аналогами 3 використанням ресурсів мережі Інтернет, що $є$ ще одним кроком до стирання «національних економічних кордонів» і переходу світового співтовариства до створення глобальної економіки.

Висновки. Як показав аналіз світового досвіду, спеціальне законодавство для регулювання сфери державних закупівель за бюджетні кошти товарів, робіт і послуг вкрай необхідне. Можна сказати, що основними негативними факторами, які гальмують розвиток держзакупівель в Україні, є розрізненість і відсутність єдиної методології в проведенні конкурсних торгів, суперечності в законодавстві стосовно питань регулювання даної сфери, відсутність кваліфікованих спеціалістів, які мають відповідати за належну організацію тендерів та їх результат, високий рівень корупції.

Враховуючи стратегічний курс України на запровадження в економічній діяльності й регулюванні економічних відносин стандартів ЄС як передумови набуття членства у Свропейському Союзі, беручи до уваги положення угод про асоціацію та вільну торгівлю з $\mathrm{CC}$, розвиток національного законодавства стосовно державних закупівель має здійснюватися у напрямку максимального наближення та імплементації норм Свропейського Союзу, насамперед закупівельних директив ЄС. Уніфікація законодавства, окрім інших можливостей, дозволить українським постачальникам брати участь у тендерах інших держав на загальних умовах.

Запровадження в Україні системи електронних закупівель, на зразок США, дозволить підвищити прозорість та ефективність використання державних коштів, знизити витрати потенційних постачальників на участь у конкурсі; забезпечить інформаційно-аналітичну підтримку процесів прийняття рішень на всіх стадіях та етапах управління державними закупівлями, зменшить негативний вплив бюрократизму, протекціонізму та суб'єктивізму під час вибору переможців конкурсних торгів, підвищить рівень конкурентності під час закупівель та забезпечить рівні умови для всіх учасників. 
Застосування стандартних контрактів допоможе уникнути зайвих витрат, пов'язаних з юридичним оформленням процесу закупівель й оцінкою заявок.

Вважаємо за доцільне рекомендувати запровадження кримінальної відповідальності за організацію змови з метою порушення процедур державних закупівель. Для забезпечення більш ефективного контролю та нагляду за реалізацією принципів державних закупівель, у тому числі щодо добросовісної конкуренції під час проведення конкурсних процедур, ефективності державних закупівель, Міністерству фінансів України було б доцільно скоординувати дії державних контрольних органів за напрямами моніторингу та контролю публічних закупівель та участі представників громадянського суспільства у цьому процесі.

Зрозуміло, що такі пропозиції мають рекомендаційний характер і можуть бути предметом наукової дискусії. До того ж, зважаючи на складність процедур закупівлі за державні кошти і значні проблеми 3 їх регулювання та контролю, наукові розвідки в даному напрямі потребують подальшого розвитку.

\section{Стаття надійшла до редакціi: 13.01.2019}

\section{UKRAINIAN REALITIES AND THE WORLD EXPERIENCE OF FIGHTING CORRUPTION IN THE FIELD OF PUBLIC PROCUREMENT}

Ljudmyla Ivashova, Doctor of Public Administration, professor, professor of the Department of Public Administration and Customs Administration, University of Customs and Finance, Dnipro, Ukraine

Mykhailo Ivashov, Candidate of Economic Sciences, Senior Researcher, Professor, Department of Public Administration and Law, Dnipro Academy of Continuing Education Dnipro, Ukraine

The article analyzes the current state and effectiveness of anticorruption measures in Ukraine, substantiates the relevance of the study of 
the experience of counteraction to corruption in the world and the necessity of its implementation in the domestic practice. The main mechanisms for overcoming corruption in the field of public procurement in Ukraine and the priority measures aimed at their implementation are determined.

The purpose of the paper is to highlight the real state and threats of corruption in the field of public procurement for the economic development of Ukraine and, based on foreign experience, identify effective mechanisms for combating corruption and their implementation in Ukraine.

The study used and summarized officially published results of scientific researches of domestic and foreign authors, statistical data, reports of state controlling bodies and international expert organizations, creative reflection on the basis of application of the system approach and methods of statistical and comparative analysis, content analysis and the synthesis of the results allowed to make substantiated conclusions.

The work substantiates that effective mechanisms of counteraction to corruption are the further development of institutional, informational and technological monitoring and monitoring of the mechanism of "electronic auctions", which, provided they are effectively used and activated by civil society, can create the necessary grounds for reducing volumes and eradicating corruption as in the field of public procurement, as well as in other spheres of vital activity of the state.

It is determined that counteracting abuses and combating corruption in the sphere of public procurement in Ukraine is at a rather low level. Therefore, overcoming corruption in the system of placing government orders is one of the most important tasks of public administration in the field of public procurement for budget funds. Positive in this direction is that the state has started to develop new mechanisms for combating corruption - the introduction of the ProZorro electronic procurement system, the launch of authorized electronic platforms and the web portal of the Authorized Purchasing Authority, the ongoing monitoring and monitoring of public procurement operations, the placement of results control on the monitoring portal DOZORRO, etc. However, the ineffective use of these tools leads to a high level of corruption in the field of public procurement. 
In order to increase the effectiveness of counteraction to corruption, taking into account the experience of foreign countries, it is proposed: to completely abandon placing an order in a single source without bidding; to improve the procedure of contesting agreements concluded with violation of the requirements of the current legislation. This will reduce the number of abuses and limit the possibility of using corruption schemes in the public procurement system for budget funds.

In general, for successful implementation of these measures, first of all, it is necessary to make changes to the institutional mechanism of public administration through the system of public procurement and to strengthen the role of state monitoring and audit on the justified and targeted use of budget funds in the public procurement system.

Keywords: public procurement, electronic auctions, state monitoring and control in the field of procurement, corruption, counteraction to corruption.

\section{Received: 13.01.2019}

\section{References}

1. Dremov, S.V., Kalnysh, Yu.G., Klimenko, D. B., Usatiy, G. O., Usachenko, L. M. (2010) Koruptsiya v Ukrayini: prychyny poshyrennya ta mekhanizmy protydiyi. Zelena knyha derzhavnoyi polityky [Corruption in Ukraine: Causes of Distribution and Mechanisms of Counteraction. Green book of state policy] Kyiv: DP "NVTS "Priorytety" [in Ukrainian]

2. Glodan S.Yu. Stan i problemy koruptsiyi v Ukrayini [State and Problems of Corruption in Ukraine] Retrieved from: https: // zakjust.gov.ua/yurydychnikonsultatsii/464-stan-i-problemy-koruptsii-v-krainian [in Ukrainian]

3. Kritenko, E. (2013) Counteraction to corruption in public procurement in Ukraine. Przemyśl: Nauka i studia. Fellowship, 4 (72), p. 79-85 [in Poland]

4. Krytenko, O. O., Pis'machenko L.M. (2010). Svitovyy dosvid derzhavnoho rehulyuvannya zakupivli za byudzhetni koshty [World experience of state procurement regulation for budgetary funds] Visnyk Akademiyi mytnoyi sluzhby Ukrayiny. Seriya: "Derzhavne upravlinnya" 1 (2), Dnipropetrovs'k: AMSU, p. 69-74 [in Ukrainian].

5. Rudoy, K.M. (2015) Zapobihannya koruptsiyi yak napryamok zabezpechennya mizhnarodnoyi bezpeky [Preventing Corruption as a Way to 
Secure International Security]. Pravova derzhava, 19. p. 69-73. Retrieved from: http://Prav_2015_19_16.pdf [in Ukrainian]

6. Taranenko, O.P. (2014) Suchasni zakhody zapobihannya koruptsiyi u sferi derzhavnykh zakupivel'. Derzhavne upravlinnya: teoriya ta praktyka [Modern measures to prevent corruption in the field of public procurement] Public Administration: Theory and Practice. 2. Retrieved from: http://academy. gov.ua/ej/ej20/PDF/4.pdf [in Ukrainian]

7. Tkachenko, N. B. (2007) Upravlinnya derzhavnymy zakupivlyamy [Public Procurement Management]: monohrafiya Kyiv: Vyd-vo "Knyha" [in Ukrainian]

8. Shatkovs'kyy, O., Fayvesh, G. (n.d.) Elektronni derzhavni zakupivli: poshuk ukrayins'koho shlyakhu [Electronic Government Procurement: Search of the Ukrainian Way] /O.P. Shatkovs'kyy, H.. Retrieved from http:// eupublicprocurement.org.ua/e-procurement-finding-a-way-forukraine. html?lang=UK [in Ukrainian].

9. Bondar, I. (2007) Derzhavni zakupivli v Shveytsariyi [Public Procurement in Switzerland] Derzhavni zakupivli v Ukrayini. 11. pp. 41-44. [in Ukrainian]

10. Buchko, O. (2009) Derzhavni zakupivli: Kanada [Public Procurement: Canada] Derzhavni zakupivli v Ukrayini. 7. pp. 42-44. [in Ukrainian]

11. Bubliy, M.P. (2011) Mizhnarodnyy dosvid orhanizatsiyi ta zdiysnennya derzhavnykh zakupivel' [International experience in the organization and implementation of public procurement] The theory and practice of public administration: sciences. Bulletin of the Kharkiv Regional Institute of Public Administration of the National Academy of Public Administration under the President of Ukraine. issue. 3. Kharkov: KHRIDU NADU. Retrieved from http://www.kbuapa.kharkov.ua/e-book/tpdu/2011-4/doc/1/05.pdf [in Ukrainian]

12. Kaydash, T. (2007) Derzhavni zakupivli v Spoluchenykh shtatakh Ameryky [Public Procurement in the United States of America] Derzhavni zakupivli v Ukrayini. 12. pp. 39 - 44. [in Ukrainian]

13. Mischenko, O. (2008) Osoblyvosti provedennya torhiv u krayinakh Tsentral'noyi ta Skhidnoyi Yevropy [Peculiarities of Bidding in Central and Eastern Europe] Derzhavni zakupivli v Ukrayini. pp. 32-40. [in Ukrainian]

14. Mishchenko, R. (2012) Elektronni zakupivli: realiyi vprovadzhennya v suchasnykh heoekonomichnykh umovakh [Electronic purchases: the realities of implementation in modern geo-economic conditions] Journal of public service. 3. - pp. 55-60 [in Ukrainian] 
15. Pappas, S. (2005) Polityka ES u sferi derzhavnykh zakupivel' [EU Policy in Public Procurement]. Kyiv: IMV KNU im. T. Shevchenka (Prohrama Tacis Yevropeys'koho Soyuzu v Ukrayini) [in Ukrainian].

16. Sidorenko, I. (2007) Systema derzhavnykh zakupivel' v Latviyi [Public Procurement System in Latvia] Derzhavni zakupivli v Ukrayini. 10. pp. 37-44. [in Ukrainian]

17. Kharchenko, G. A. (2009) Mizhnarodnyy dosvid u systemi derzhavnykh zakupivel' [International Experience in the System of Public Procurement] Ekonomika ta derzhava. 11. pp. 200-204 [in Ukrainian].

18. (2016) Strashni vidomosti prynesly sotsiolohichni doslidzhennya [Terrible information brought by sociological research] S·H Reytynh Chynnist' zakonu Retrieved from http://www.rol.org.ua/newsitem.cfm?unid=5594 [in Ukrainian]

19. (n.d.) Kozhna tretya ukrayinka/ets' hotovi doluchytysya do orhanizovanoyi protydiyi koruptsiyi [Every third Ukrainian woman is ready to join the organized counteraction to corruption] / Retrieved from /https://dif.org. ua/article/kozhna-tretya-ukrainkaets-gotovi-doluchitisya-do-organizovanoiprotidii-koruptsii [in Ukrainian]

20. (2019) Koruptsiya v Ukrayini spryynyattya, dosvid, stavlennya: analiz zahal'nonatsional'nykh opytuvan' 2015-2018 [Corruption in Ukraine perception, experience, attitudes: analysis of nationwide polls 2015-2018] Retrieved from https:/dif.org.ua/uploads/pdf/ 6343688805c078ceeea4aa6.97852084.pdf [in Ukrainian].

21 (2006) Corruption assessment: Ukraine. views: final report Retrieved from https://pdf.usaid.gov/pdf_docs/PNADK247.pdf. Washington [in English]

22. Rachkevych Mark (2011) Under Yanukovych, Ukraine Slides Deeper In Ranks Of Corrupt Nations (Eng.). Kyiv Post (1 December 2011) Retrieved from https:/www.kyivpost.com/article/ content/ukraine-politics/under-yanukovychukraine-slides-deeper-in-ranks-of-118032.html [in Ukrainian]

23. (2015) Rezul'taty doslidzhennya «Stan koruptsiyi v Ukrayini dlya proektu UNITER» [Results of the study "The state of corruption in Ukraine for the UNITER project"] Retrieved from http://www.uniter.org.ua/ukr/press/ uniter-project-anti-corruption-perception-survey-2015.html [in Ukrainian]

24. (2015) 2015-y: politychni pidsumky-dumka naselennya (doslidzhennya provely Fond «Demokratychni initsiatyvy imeni Il'ka Kucheriva» ta Kyyivs'kyy mizhnarodnyy instytut sotsiolohiyi z 15 po 25 hrudnya 2015 roku) [2015: Political Results - Public Opinion [The study was conducted by the Ilko Kucheriv Democratic Initiatives Foundation and the Kyiv International Institute 
of Sociology from December 15 to 25, 2015] Retrieved from http://dif.org.ua/ ua /publications/press-relizy/2015-i-pol.-pids.html [in Ukrainian]

25. (2015) Monitorynhove opytuvannya hromads'koyi dumky naselennya Ukrayiny, provedene Ukrayins'kym instytutom sotsial'nykh doslidzhen' im. O. Yaremenka ta Tsentrom «Sotsial'nyy monitorynh» [The monitoring survey of public opinion of the population of Ukraine, conducted by the Ukrainian Institute of Social Studies them. O. Yaremenko and the Social Monitoring Center] Retrieved from http://www.uisr.org.ua/ [in Ukrainian]

26. Shatkovsky O., Götler P. (n.d.) Novyy zakon Ukrayiny pro derzhavni zakupivli cherez pryzmu mizhnarodnykh standartiv [The New Law of Ukraine on Public Procurement through the Prism of International Standards] / O. Shatkovsky] Harmonizatsiya system konkurentsiyi ta derzhavnykh zakupivel' Ukrayiny zi standartamy ES. Retrieved from http://competitionproject. org.ua/ en/publishing/pres-relzi/ 125-lexpeterarticleujbl.html [in Ukrainian]

27. (2019) Derzhaudyt·sluzhba prosyt' posylyty vidpovidal'nist' zamovnykiv. Yedynyy vebportal orhaniv vykonavchoyi vlady Ukrayiny [The State Service requests that the responsibility of the customers be strengthened. The only web portal of executive bodies of Ukraine. Retrieved from: https://www. budgetnyk.com.ua/news/1432-derjauditslujba-prosit-posiliti-vdpovdalnstzamovnikv?from=PW_Click_Budgetnyk\&ustp=W [in Ukrainian]

28. Yedynyy vebportal orhaniv vykonavchoyi vlady Ukrayiny. The only web portal of executive bodies of Ukraine. Retrieved from https://www. budgetnyk.com.ua/news/1432-derjauditslujba-prosit-posiliti-vdpovdalnstzamovnikv?from=PW_Click_Budgetnyk\&ustp=W [in Ukrainian]

29. Brun-Nielsen, S. (2015) Derzhavni zakupivli: shist' klyuchovykh urokiv vid ES [Public Procurement: Six Key Lessons from the EU] Yevropeys'ka pravda. Retrieved from http: // www.eurointegration.com.ua/ articles/2015/06/4/7034467/[in Ukrainian]

29. Yeshchenko, P. S. (2011) Dohmy i realiyi "novoyi ekonomiky" [Dogma and the realities of the "new economy"] Teoretychni ta prykladni pytannya ekonomiky Zbirnyk naukovykh prats'. Issue 24 Kyiv: Publishing and Printing Center "Kyiv University" pp. 13-22. [in Ukrainian]

30. (2016) Zakon Ukrayiny Pro publichni zakupivli vid 25.12.2015 r. \#922VIII . Z podal'shymy zminamy [On Public Procurement: Law of Ukraine dated December 25, 2015 \# 922-VIII. With further changes] Vidomosti Verkhovnoyi Rady (VVR). 9. St. 89. [in Ukrainian]

32. Ovisnyuk, O. (2005) Komparatyvnyy analiz systemy derzhavnykh zakupivel' krayin Yevropeys'koho Soyuzu [Comparative Analysis of the Public 
Procurement System of the European Union Countries] Naukovi zapysky. Issue 14. pp. 32-34[in Ukrainian]

\section{Відомості про авторів / Information about the Authors}

Івашова Людмила Миколаївна: Університет митної справи та фінансів: вул. Володимира Вернадського, 2/4, м. Дніпро, 49000, Україна

Ljudmyla Ivashova: University of Customs and Finance: street. Volodymyr Vernadsky, 2/4, Dnipro, 49000, Ukraine

\section{ORCID.ORG/ 0000-0003-3176-919X}

\section{E-mail: pln1204@ukr.net}

Івашов Михайло Федорович: Дніпровська академія неперервної освіти вул. Володимира Антоновича, 70, м. Дніпро, 49006 Україна

Mykhailo Ivashov: Dnipro Academy of Continuing Education street. Volodymyr Antonovich, 70, Dnipro, 49006 Ukraine

ORCID.ORG/ 0000-0002-2127-2676

\section{E-mail: imf77@ukr.net}

